\title{
47. Some Ecological Observations of Rana ishikawae, a Rare Frog Endemic to the Ryukyu Islands
}

\author{
By Yasuaki UtsunomiYa,*) Taeko Utsunomiya,*) \\ and Seiki KATSUREN**) \\ (Communicated by Sajiro Makino, M. J. A., May 12, 1979)
}

Rana ishikawae STEJNEGER, a rare and beautiful frog, was described first by Stejneger $(1901,1907)$ on the basis of a formalinreserved specimen. Later, Hirose (1929) reported a living specimen of this species from Okinawahonto. Further, Okada (1931), based on some observations of three specimens from Heto and Genka, stated that the present species was very rare in occurrence and spawning was taken place in holes in old trees of Palaeczoic formation. Koba (1957) described a single specimen in Genka as being very rare and noted that some specimens were found in 1956 and 1958 in Amamioshima and Tokunoshima. The above reports had not been based on personal collections, except the case of Koba (1956) in Tokunoshima. Recently, Suzuki (1974) and Maeda (1977) described this soecies in Amamioshima, and Chikira (1977) in Okinawahonto.

By the distributional surveys of frogs carried out by Ikehara and Katsuren (1976), some 16 individuals of this species have been obtained near the Aha river. By means of a "marking method" made through a year, Ikehara and Akamine (1976) collected five specimens of this species near the Fuku river. Recently Katsuren, Tanaka and Ikehara (1977) have contributed something to the ecological features of this species particularly on the spawning habit. During a period from 1976 to 1978 , we undertook some collection surveys of frogs in the Ryukyu Islands, with special regard to their breeding habit. The data are presented in this paper.

Because of the facts that the present species are dwelling in mountain streams in wooded areas, and that they are nocturnal in behavior, the observations are made by night with considerable obstacles. While our surveys were extended to almost all rivers in Okinawahonto such as the Genka, Nyuha, Ura, Yona, Fuku, Aha, Arakawa and Shinegaki, we were able to observe their breeding in the areas of the Aha, Nyuha and Ura rivers. In Amamioshima we inves-

*) Department of Food Chemistry and Technology, Faculty of Fisheries and Animal Husbandry, Hiroshima University, Fukuyama.

**) Habu Research Branch Station, Okinawa Prefectural Institute for Public Health, Urasoe. 
tigated 6 branch streams from the Agina river, and found there some larvae and adults. Especially we collected some specimens in the Shinokawa village and the central part of Koniya town. Very probably, some specimens came down from mountainous regions by rainflow.

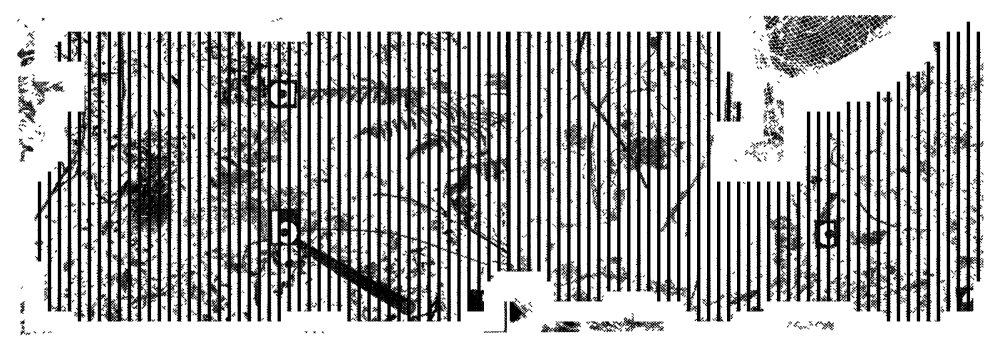

Fig. 1. A spawning hole of Rana ishikawae. 1: Front view of the entrance which was arranged by removing mud and rock from " $a$ " to "b". 2: The eggs scooped up from the entrance "c" of the hole.
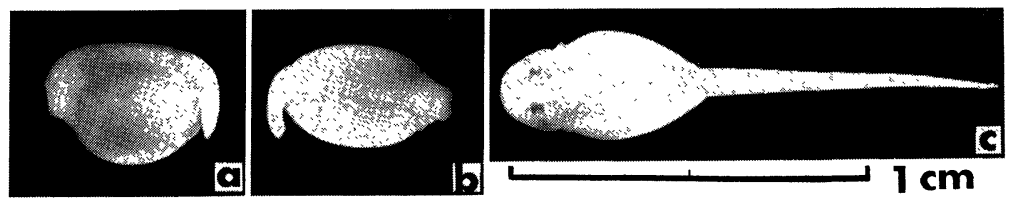

Fig. 2. Larvae Rana ishikawae, seven days after collection (Feb. 12, 1978).

Notes on breeding: The spawning was observed in holes along side slopes of an upper stream near the river head. The diameter of the entrance of every hole was nearly corresponding to the body-size of the adult. The entrance of the hole was located more or less than $150 \mathrm{~cm}$ high from the bottom of the river. The holes lying close to the water surface as reported by Katsuren, Tanaka and Ikehara (1977) were very rare. In February 5, 1978, we chanced to observe another hole near the Aha river (Fig. 1). The inside of the hole was considerably wide and surrounded by rocks with stagnant water. A male stout frog was found in the hole. The water temperature was $16^{\circ} \mathrm{C}$ in the hole and $13^{\circ} \mathrm{C}$ in the river. The male frog made occasionally loud mating calls with right and left vocal sacs. There were found many eggs in the hole water, some of which were collected for observation. The eggs had been in different developmental stages. The youngest one was at the 64-cell stage. The egg color was yellowish white, having no pigment. This made difficult the observation of their developmental condition. The egg diameter was about $4.3 \mathrm{~mm}$ and about $11 \mathrm{~mm}$ with jelly capsule. The outside of the jelly capsule was free from adhesiveness, and eggs easily came to piece from each other. The above fact seems to indicate that a single male independently locates 
in a single hole and invite alternately different females in the same hole. Spawning seems to be taken place at different times under this situation, and consequently eggs at different developmental stages are to be obtained in the same hole.

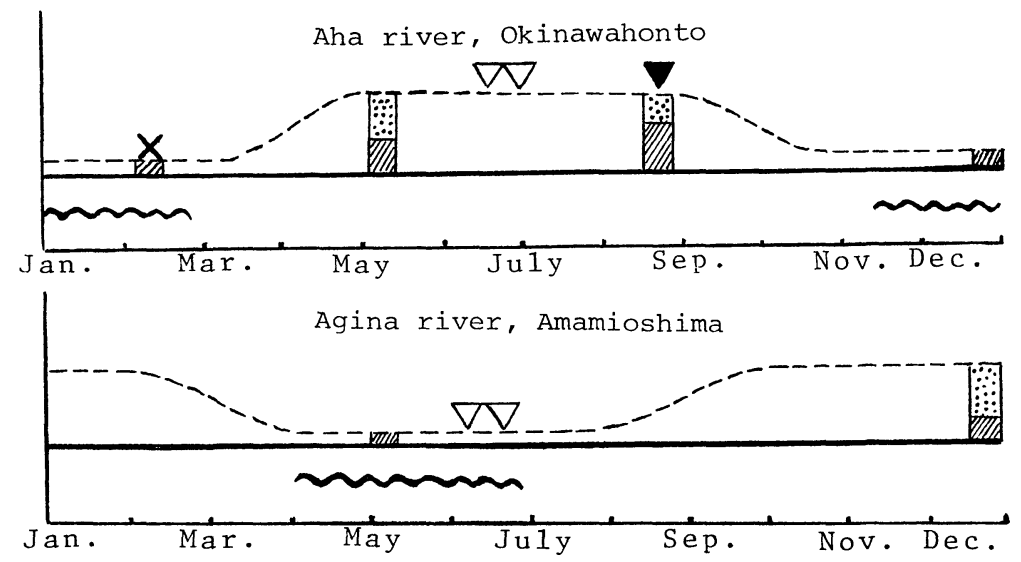

Fig. 3. Seasons of the appearance of larvae of Rana ishikawae, from observations in Okinawahonto and Amamioshima. Larvae less than $40 \mathrm{~mm}$ in whole length. length. $\times$ The period when spawning observed. $\nabla$ The period when metamorphosis was observed. $\nabla$ The period when metamorphosis was observed in laboratory. $\sim$ The period when mating calls were catched.
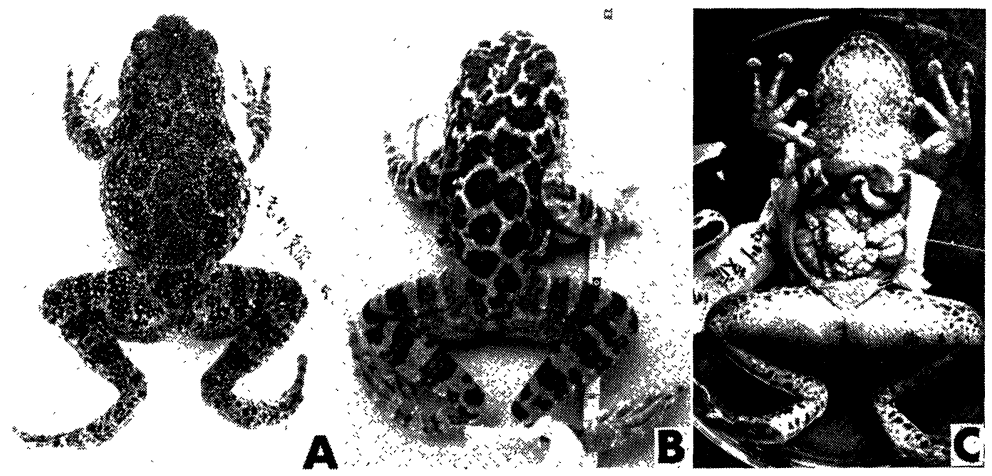

Fig. 4. Adults of Rana ishikawae. A, a female from Amamioshima; $120 \mathrm{~mm}$ in length. B, a male from Okinawahonto; $110 \mathrm{~mm}$ in length. $\mathrm{C}$, ovaries and corpulent oviducts of a female individual (A) (collected on May 4).

Seven days later, the eggs were cultured in the water kept at $15^{\circ} \mathrm{C}$. The eggs were at younger developmental stages. They hatched during from 12 to 15 days after collection. The larvae were $12 \mathrm{~mm}$ in the whole length (Fig. 2). They metamorphosed during a period 
from June 16 to 28.

Notes on the breeding season: In Okinawahonto, we were able to catch mating calls during from November to February (Fig. 3). The spawning was observed in early February. In Amamioshima, the spawning hole of this species has not yet been found, but the mating calls were catched during a period from spring to early summer (Fig. 3). One female was collected on the 4th of May near the Agina river. She carried mature eggs, $3.3 \mathrm{~mm}$ in diameter, in her ovaries and her oviducts were corpulent (Fig. 4).

Notes on larvae: The well-developed larvae of this species were obtained in a slow current of the upper stream through a year, in the Aha river, Okinawahonto, and in the Agina river, Amamioshima. In the Aha river, many young larvae were observed in summer, while they were in the winter season in the Agina river (Fig. 3). The larvae thus obtained completed metamorphosis during a period from June to July. In the Aha river, metamorphosed larvae were obtained in August. Then, it seems probable that there may be some specimens which have remained without metamorphosis in the summer season.

Notes on morphology: In comparison of some morphological characters in adults obtained in Okinawahonto and Amamioshima, it was found that there was a considerable difference among individuals in the spotting and the tubercle on their backs (Fig. 4, A and B). The young frogs cultured in the laboratory showed also some differences in their back spots and tubercles.

Remarks. The literature refers to a report of Koba (1965) on a single young frog of this species from Tokunoshima lying between the Okinawahonto and Amamioshima islands. However, our surveys carried out for five or more years have failed to find larvae or adults of this species in Tokunoshima. In the present situation, therefore, we have no comment on this species from Tokunoshima. Inger (1947, 1950 ) is of opinion that the amphibians of the Ryukyu islands show various grades of evolution according to their isolation in the islands. On the basis of our present observations, it is very probable that the present species show considerable variations either in their morphological characters or in breeding habit according to the environmental conditions of the islands.

Summary. Morphological characters and breeding habits of Rana ishikawae are observed in some detail in Okinawahonto and Amamioshima. During the breeding season, a male frog has stayed in a hole along waters. He invites different females by calling to the same hole, and spawnings are made by these females at different times.

The breeding season seems to be taken place in the winter season in Okinawahonto, while from spring to early summer in Amami- 
oshima.

Well-developed and young larvae are observed in summer in Okinawahonto, while in winter in Amamioshima. Well-developed larvae are obtained in streams of both islands through the year.

A considerable morphological difference is present on the back spot and tubercles between the frogs from Okinawahonto and Amamioshima.

Acknowledgements. Our thanks are expressed to Professor Sadao Ikehara, University of the Ryukyus, for many facilities and to Messrs. M. Toyama, H. Akamine, K. Shimamura, Y. Chikira, other students of University of the Ryukyus, and $H$. Hiramine of the Kagoshima Prefectural Education Center for their kind collaboration for this survey, and also to members of the Amami Branch Laboratory, Institute of Medical Science, University of Tokyo for permitting us to inspect the specimens. We are very grateful to Emeritus Professor Sajiro Makino, M. J.A., for this expert revision and improvement of this manuscript with invaluable advice.

\section{References}

Chikira, Y. (1977) : Rep. Nat. Monum., ser.1, Nago, Okinawa.

Hirose, K. (1929) : Amoeba, vol. 1, no. 1, pp. 44-48.

Inger, R. F. (1950) : Amer. Naturalist, 84, 95-115.

Ikehara, S., and S. Katsuren (1976) : Ecol. Stud. Nat. Cons. Ryukyu Isl., 2, 81-88.

Ikehara, S., and H. Akamine (1976) : Ecol. Stud. Nat. Cons. Ryukyu Isl., 2, 69-80.

Katsuren, S., S. Tanaka, and S. Ikehara (1977) : Ecol. Stud. Nat. Cons. Ryukyu Isl., 3, 49-54.

Koba, K. (1955) : Mem. Fac. Edu. Kumamoto Univ., 3, 152.

- (1956) : Mem. Fac. Educ. Kumamoto Univ., 4, 155. (1957) : Mem. Fac. Educ. Kumamoto Univ., 5, 198-199. (1958) : Mem. Fac. Educ. Kumamoto Univ., 6, 183.

Maeda, N. (1977): Nippon Herp. J., 8, 25-27.

Okada, Y. (1931) : Tailless Batrachians of the Japanese Empire, Tokyo.

Stejneger, L. (1901) : Proc. Biol. Soc. Wash., 14, 190.

- (1907) : U. S. Nat. Mus., 58, 132-134.

Suzuki, H. (1974) : Anima, 19, 68-73. 